\title{
Flash Flood Climatology in the Lower Region of Southern Sindh
}

\author{
Ali Asghar Mahessar \\ Sindh Barrages Improvement Project, \\ Sindh Irrigation Department, Pakistan \\ amahessar@yahoo.com
}

\author{
Abdul Latif Qureshi \\ USPCAS-W, Mehran University of \\ Engineering and Technology, Pakistan \\ alqureshi.uspcasw@faulty.muet.edu.pk
}

\author{
Insaf Ali Siming \\ Department of English, \\ QUEST, Nawabshah, Pakistan \\ insaf.siming@quest.edu.pk
}

\author{
Shafi Muhammad Kori \\ USPCAS-W, Mehran University of Engineering and Technology, \\ Jamshoro, Pakistan \\ alqureshi.uspcasw@faulty.muet.edu
}

\author{
Ghulam Hussain Dars \\ USPCAS-W, Mehran University of Engineering and \\ Technology, Jamshoro, Pakistan \\ ghdars.uspcasw@faculty.muet.edu.pk
}

\author{
Madeheea Channa \\ USPCAS-W, Mehran University of Engineering and Technology, \\ Jamshoro, Pakistan \\ madhachana.uspcasw@admin.muet.edu.pk
}

\author{
Abdul Nasir Laghari \\ Department of Energy and Environment Engineering, QUEST, \\ Nawabshah, Pakistan \\ a.n.laghari@quest.edu.pk
}

\begin{abstract}
Climate change impact is felt at a global scale. One of its results is the abnormal rain occurrence during monsoon season. In recent years, visible changes due to unusual weather events in Pakistan's hydrological cycle were observed in the form of intensification of the hydrological cycle with changing of precipitation events such as floods and prolonged droughts. Hence, abnormal rainfall occurred in regions of southern and northern parts of Sindh, like torrential river floods (2010), flash floods (2011-2012), unpredictable rainstorms, etc. causing loss of lives, damaging infrastructures and crops, structures, and inhabitant displacement. In 2011, heavy cumulative precipitation has been recorded in the southern Sindh districts and the coastal belt of Badin and the LBOD and Kotri surface drainage system achieved their extreme heights. Another example of erratic rain occurred from September 8 to September 13, 2011 and produced an extraordinary discharge of about 14000 cusecs against the designed discharge of 4600 cusecs in the LBOD and Kotri surface drainage systems overtopping drains from several locations and wreaking havoc in the whole area of the southern part of Sindh.
\end{abstract}

Keywords-climatology; rainfall; flood; LBOD watershed area; drain carrying capacity; damages

\section{INTRODUCTION}

Climate variables such as rain, wind and temperature can sometime reach abnormal values and create natural disasters. These are termed as extreme events. Changes in global precipitation estimate are a more complex and challenging task than the changes in temperature. Extreme precipitation events often occur in populated areas causing disaster and affecting population. Changes in extreme events such as torrential rainfall, cyclone, irregular temperatures, heat waves, prolonged droughts and floods are mainly caused by climate change [1,
2], and Pakistan is one of the most vulnerable to climate change countries [3]. Global climate change experts have identified Pakistan as part of a zone that faces extreme changes in weather. Climate change and environmental crises in vulnerable areas of Pakistan indicate that $40 \%$ of the population is highly vulnerable to natural disasters [4]. Developing countries including Pakistan will be affected by serious droughts, floods, increasing temperatures, and lifethreatening events [5]. Climate change risk is proposed to be an ambiguity related to the influence of climate change in specific areas of concern [6]. Scientifically guesstimating the conceivable influences of future climate modification is the precondition to demeanor alteration activities. At primary period, the growing situation is regularly used to project the future influences of climate [7]. Temperature will rise from 0.9 to $3.5^{\circ} \mathrm{C}$ by 2100 , causing fluctuation in intensity, frequency and timing of rainfall, frequent hot days/nights occurrence and changed effects of biotic factors [8]. High temperature, reduction in rainfall occurrence, and an increase in the frequency of extreme climatic events are expected in the future climate of the tropics [5,9]. The change in the weather disturbed life and cropping pattern. This expected deviation in climate has effects on the food chain and other segments through spatial and temporal scales $[5,10]$. The frequency and severity of floods in some areas during the monsoon have serious impacts [12]. Cyclone formations and irregularities in rainfall pattern are related consequences of global warming. Global warming is closely linked to the seasonal atmospheric flow during the monsoon season with varying degree of uncertainty. Irregular flooding is a serious repercussion of the monsoon season that damages infrastructure, human life and causes serious financial losses $[11,13]$. The worst flood 
disaster in the 80 year history of Pakistan occurred in July 2010 with following heavy monsoon rains [14]. From July to September, the summer rainfall concentrates, which is generally a monsoon breath formed on the Bengal Bay reaching Pakistan across India. Another mechanism of summer monsoon rainfall is the flow of moisture from the Arabian Sea in the southwest and it will be activated in case of persisting depression. Both phenomena strengthen the precipitation process and produce high intensity rainfall in a short time $[15$, 16]. Coastal areas may suffer from increased tropical storm frequency and strength in the near future, while over 50,000 people may be displaced from Pakistan's coastal deltas [17]. The southern part of Sindh has been affected with strong rains, cyclones, high tides, causing damages in life, property, crops and causing waterlogging and soil salinity. Kotri surface drainage and Left Bank Outfall Drain (LBOD) system [3] were designed and constructed primarily aiming to provide effective drainage facilities to address the issues of waterlogging, salinity and generated rain runoff. This system fulfilled its purpose and provided rainwater release from its watershed area timely but a severe submergence of lands of Badin district occurred during the erratic rainstorms of 1994 and 2003 ranging from 200 to $304 \mathrm{~mm}$ respectively. The generated rain runoff exceeded the carrying capacity of LBOD and Kotri surface drainage system causing long term massive area submergence and damaging infrastructures and crops, while it increased the waterlogging problem. Moreover, the components of the LBOD system were overtopped at the heavy rain of 2006. From the historical rainfall data of 39 years of meteorological stations, Table I shows the maximum rainfall in 24 hours in the watershed area of LBOD and Kotri surface drainage system. When the rainfall intensity is low there is no problem of safe disposal, but with high intensities that overcome the designed carrying capacity of the system, over extensive areas are submerged. The overall discharge passing through the outfall drains depends upon the weighted average rainfall for all the meteorological stations representing the entire catchment area. After the construction of Kotri and LBOD surface drainage systems, rainfall intensity of more than $100 \mathrm{~mm}$ within $24 \mathrm{~h}$ at one or more stations was recorded in 1994, 1999, 2003 and 2006 and caused severe damages [18]. The rain runoff during the monsoon in 2011 generated cumulative discharge of about 14000 cusecs while the designed carrying capacity of the LBOD system was only 4600 cusecs, resulting in damages of the drainage system at several places and causing flooding in huge areas.

\section{RESEARCH STUDY AREA}

The present study covered the watershed area of Kotri surface drainage and LBOD system which was designed to control the problems of waterlogging and salinity, and the generated rain runoff from Benazirabad, Sanghar, Mirpurkhas districts and Badin area in the Left Bank of Indus River with the objective of improving the cultivable area of Rohri and Nara canals. The drainage system lies between $24010^{\prime}$ and 260 $40^{\prime} \mathrm{N}$ and $68009^{\prime}$ and $69026^{\prime} \mathrm{E}$ [19]. Waterlogged and salinized lands will be reclaimed due to the construction of the drainage system [20], however, the performance of the system was found to be unsatisfactory during the monsoon rains in 2003 and 2006 causing the submerging of vast parts of Badin.
Moreover, it was exacerbated during the ever highest rainfall intensity recorded from 29th August 2011 to 13th September 2011 as shown in Figure 1.

TABLE I. MAXIMUM RAINFALL IN SINDH DISTRICTS (mm)

\begin{tabular}{|c|c|c|c|c|}
\hline Years & Hyderabad & Badin & Shaheed Benazirabad & Chhor \\
\hline 1968 & 7.40 & 4.60 & 3.60 & 17.50 \\
\hline 1969 & 3.00 & 0.00 & 13.20 & 4.10 \\
\hline 1970 & 67.60 & 117.60 & 59.70 & 61.00 \\
\hline 1971 & 18.00 & 42.20 & 8.60 & 51.30 \\
\hline 1972 & 12.70 & 29.70 & 256.50 & 21.80 \\
\hline 1973 & 21.80 & 35.60 & 17.30 & 32.80 \\
\hline 1974 & 12.70 & 13.60 & 0.50 & 5.00 \\
\hline 1975 & 29.10 & 61.00 & 52.00 & 40.00 \\
\hline 1976 & 57.60 & 64.70 & 32.80 & 58.40 \\
\hline 1977 & 47.40 & 60.80 & 22.00 & 88.60 \\
\hline 1978 & 106.60 & 43.50 & 73.00 & 87.20 \\
\hline 1979 & 41.60 & 241.00 & 64.00 & 29.00 \\
\hline 1980 & 41.00 & 27.00 & 40.90 & 11.00 \\
\hline 1981 & 17.70 & 138.00 & 51.20 & 42.20 \\
\hline 1982 & 26.30 & 75.60 & 42.60 & 35.30 \\
\hline 1983 & 101.70 & 67.40 & 48.20 & 119.90 \\
\hline 1984 & 110.30 & 111.00 & 48.00 & 83.60 \\
\hline 1985 & 30.70 & 55.70 & 35.90 & 97.60 \\
\hline 1986 & 69.90 & 61.10 & 99.00 & 48.30 \\
\hline 1987 & 14.20 & 0.00 & 0.00 & 23.70 \\
\hline 1988 & 60.40 & 124.70 & 13.30 & 88.60 \\
\hline 1989 & 79.20 & 95.40 & 27.50 & 86.60 \\
\hline 1990 & 58.00 & 159.30 & 87.50 & 214.60 \\
\hline 1991 & 6.50 & 36.00 & 26.00 & 20.00 \\
\hline 1992 & 104.30 & 80.00 & 97.00 & 117.00 \\
\hline 1993 & 27.00 & 119.00 & 29.20 & 123.40 \\
\hline 1994 & 76.70 & 176.50 & 143.00 & 81.30 \\
\hline 1995 & 31.20 & 88.00 & 72.20 & 60.00 \\
\hline 1996 & 6.30 & 12.00 & 1.20 & 69.50 \\
\hline 1997 & 12.00 & 31.00 & 30.00 & 36.30 \\
\hline 1998 & 19.40 & 45.20 & 22.00 & 52.30 \\
\hline 1999 & 36.10 & 113.50 & 8.00 & 107.20 \\
\hline 2000 & 25.80 & 46.80 & 22.00 & 32.90 \\
\hline 2001 & 40.50 & 26.10 & 16.80 & 70.40 \\
\hline 2002 & 4.00 & 26.00 & 2.00 & 2.30 \\
\hline 2003 & 71.00 & 150.40 & 61.00 & 137.20 \\
\hline 2004 & 85.60 & 73.00 & 11.80 & 57.80 \\
\hline 2005 & 15.40 & 23.00 & 26.30 & 32.10 \\
\hline 2006 & 46.00 & 60.00 & 46.00 & 141.20 \\
\hline
\end{tabular}

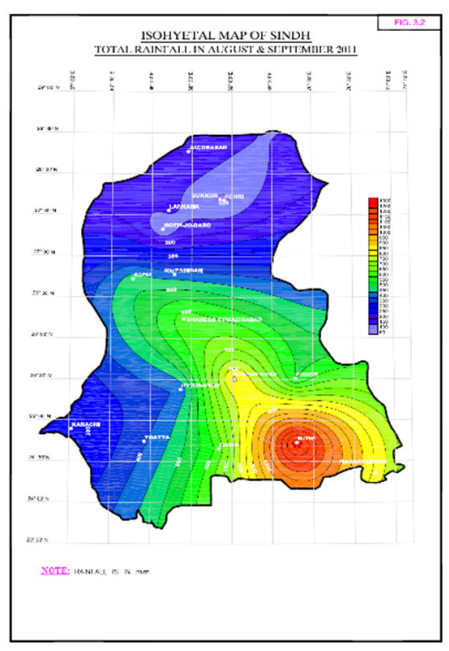

Fig. 1. Intensity of Rainfall, 2011 


\section{Methodology}

A walk through survey was conducted in the 2011 flood which damaged standing crops, communication infrastructure, irrigation and drainage systems, villages, towns and cities in the lower part of southern Sindh and also changed the lake ecosystem. Two to three feet of rainwater was observed to be standing in major roads and lowlands in various Sindh areas. Rainfall data of years 2011 and 2012 which were recorded at various rain gauge stations by the Irrigation and the Meteorological Department were collected for computing rainfall statistics. The collected rainfall data have been analyzed in order to prepare the present and future strategy, and to customize flood management plans for controlling flood risk.

\section{RESULTS AND DISCUSSION}

Most flash floods were caused from heavy rainfall. An understanding of flash flood climatology helps to develop tools to identify the risk of flooding and the likely timescale involved [21]. Eventough abnormal rains and cyclones are nowadays common phenomena, they are major causes of damages. Frequently heavy rains hit in 2010 the whole area of Pakistan, in 2011 the southern part of Sindh and in 2012 the Northern part of Sindh, but the mostly severe rainfall occurred in 1992, 1994, 2003 and 2006 in the same region of South Sindh. Figure 2 shows the rainfall occurring in Badin, Benazirabad and Tharparkar Chhor during the events of July and August of 1994.

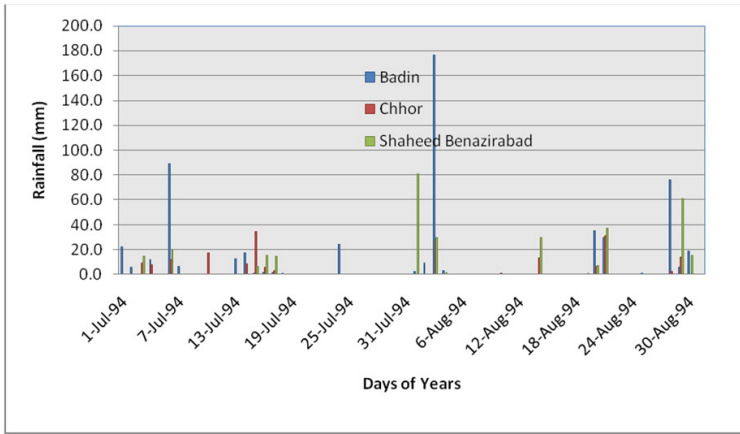

Fig. 2. Rainfall in LBOD watershed area during the monsoon of 1994

August rains generated heavy runoff because the watershed area was already saturated and filled with water during July. The rain flood damaged crops, irrigation and drainage systems, road infrastructures, and cost many human lives. Figure 3 shows the rainfall in Badin, Chhor and Benazirabad for the same period of 20003 . We see that the rainfall varied from 20 to $155 \mathrm{~mm}$ but with a higher intensity in Badin. It rained with severe intensity in the lower region of southern Sindh during 2003 and with low intensity in the upper region of northern Sindh. The first event of heavy rain occurred in 25-29 July and the second, in the lower region, on 26 August of 2003. The generated rain runoff was higher than the designed carrying capacity of the lower drainage system, so rainwater stagnated for months. This stagnant rainwater caused damages to agricultural lands and crops, infrastructure communication systems, and irrigation and drainage networks.
Figure 4 shows that rainfall variation during the monsoon of 2006. Unusual rains occurred in Badin, Benazirabad and Chhor area from 25 to 30 of July. The rain flood intensity was higher than the carrying capacity of the lower drainage system which flooded the entire area of the lower region and coastal belt. Crops and communication systems were damaged in the affected area. The phenomenon of abnormal rainfall is often observed in the coastal area of southern Sindh so the locals have become frequent victims of rain related disasters. Figure 5 reveals that heavy rainfall in 2010 occurred in the catchment area of Indus River from the Glacier to Arabian Sea which caused many breaches in the protected banks of Indus River and damages in communication infrastructures, buildings, crops, causing losses in human lives in the provinces of Pakistan, i.e. KPK, Punjab and Sindh except Baluchistan.

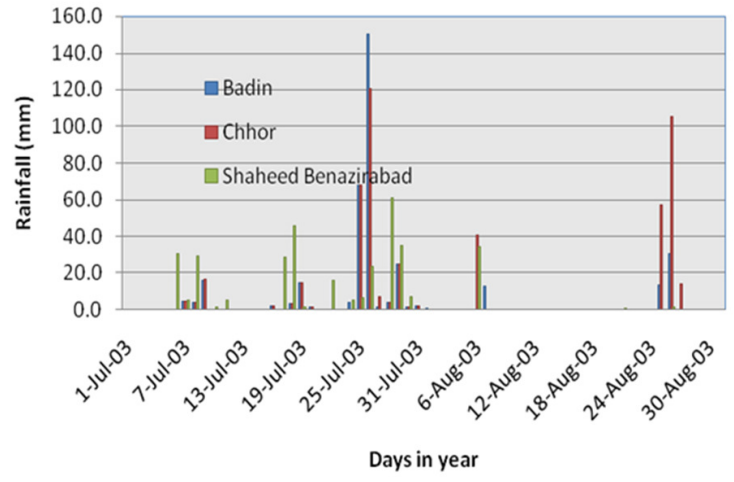

Fig. 3. Rainfall in LBOD watershed area during the monsoon of 2003

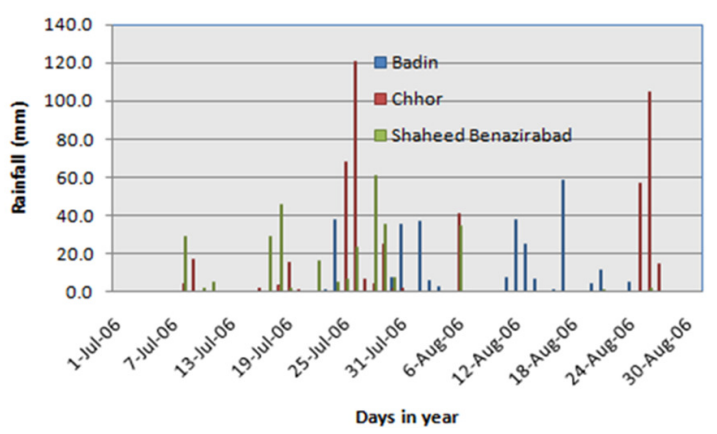

Fig. 4. Rainfall in LBOD watershed area during the monsoon of 2006

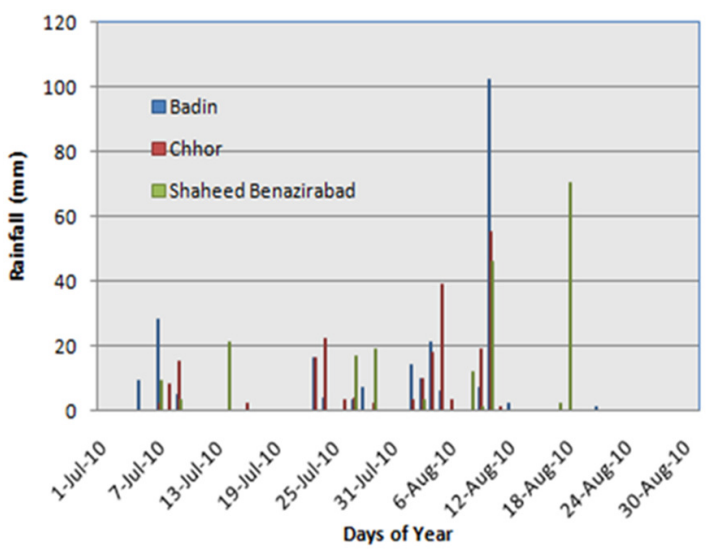

Fig. 5. Rainfall in LBOD watershed area during the monsoon of 2010 
However, rains in the lower region of the left side of Indus in Sindh province occurred with low intensity with $100 \mathrm{~mm}$ in Badin and $70 \mathrm{~mm}$ in Benazirabad (Figure 5). Hence, no loss of life and property occurred in 2010 in the lower region of Sindh. Figure 6 shows that heavy rainfall occurred in Methi, Badin, Benazirabad and Chhor in August-September of 2011 in the watershed area of the Left Bank command area of Sukkur and Kotri barrages.

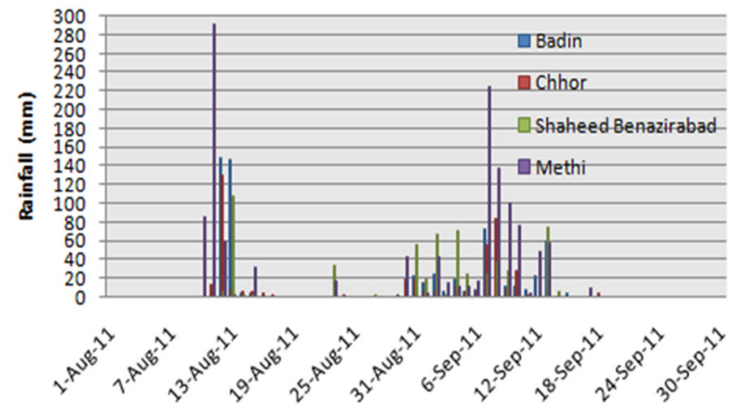

Days of Year

Fig. 6. Monsoon rainfall in LBOD catchments, August-September, 2011

The recorded maximum rainfall was $300 \mathrm{~mm}$, occurred within 24 to 48 hours and was 8 to 10 times higher from the designed capacity of LBOD and Kotri surface drainage system. The main events occurred on August 11 and 29 and continued with intervals until September 13 when the highest rainfall in the history of Sindh was recoded, which shows the unpredictable rainfall pattern in this area due to climate change. Figure 7 exhibits the relation between normal and abnormal (2011) rainfall in Pakistan, KPK, Punjab, Balochistan, and Sindh. The highest rainfall deviation error among the provinces of Pakistan was found in Sindh. The rain floods of 2011 were unique in intensity, spread and simultaneous recurrence in the lower region of Sindh province.

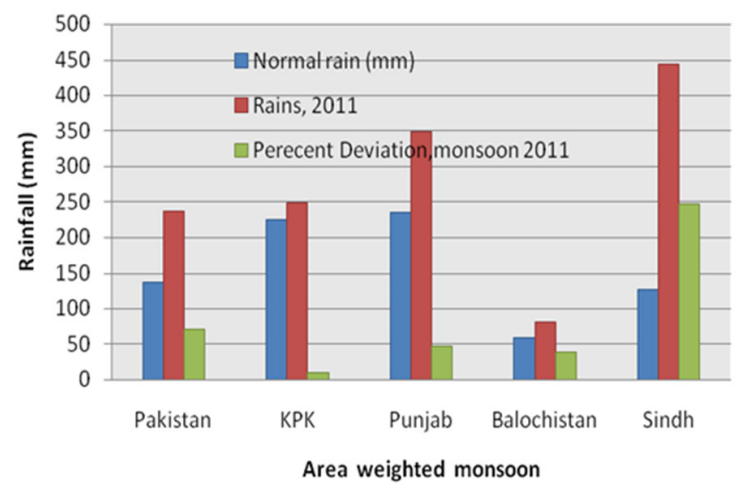

Fig. 7. Percentage of deviation of 2011 monsoon (July-August)

Figure 8 shows the recoded erratic rainfall in Badin, Mirpurkhas, Mithi, Umerkot, Benazirabad and Hyderabad $(600 \mathrm{~mm}, 820 \mathrm{~mm}, 1100 \mathrm{~mm}, 500 \mathrm{~mm}$ and $300 \mathrm{~mm}$ respectively).

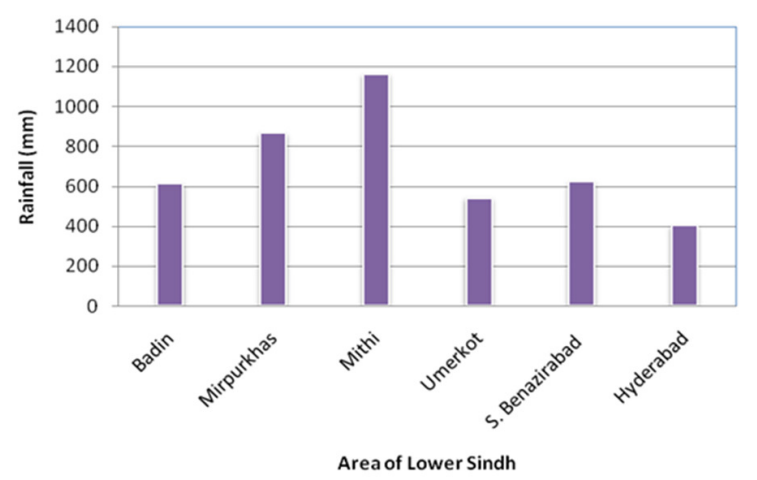

Fig. 8. Highest rainfall recorded in the districts of southern Sindh in August-September of 2011

The intensity of rainfall was so high that not only damaged almost all the catchment area of the LBOD system, but also other parts of Sindh. The rainfall at the lower region during the July-August of 2011 interval is shown in Figure 9. The rainfall water flooded lower region districts like Badin, Methi, Nawab Shah (Benazirabad), Mirpurkhas with highest intensity while the upper region districts such as Jacobabad, Larkana, Sukkur, Rohari, Dadu, Moin-Jo-Daro and Dadu received low intensity and even less rains. As a result the rainstorm in the lower region affected all structural and non-structural activities.

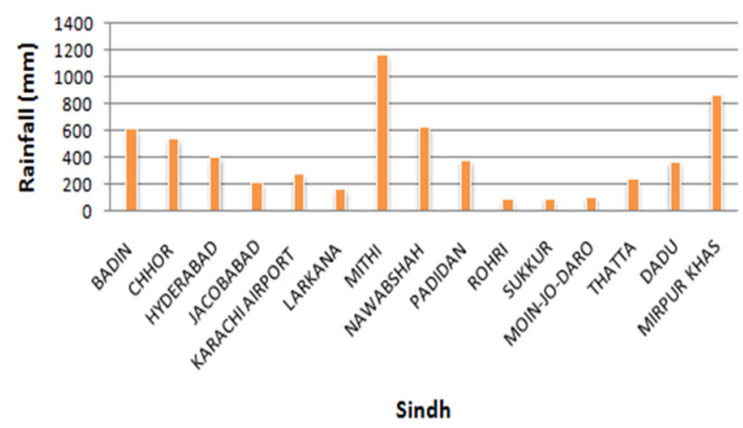

Fig. 9. Rainfall in Sindh districts during July-August, 2011

In the northern part of Sindh, there is a limited facility of surface drainage for agricultural runoff and waterlogged areas and existing surface drainage has no carrying capacity to drain out abnormal rains. The heavy rain flood of 2011 caused damage to crops, villages, towns, cities and road infrastructures. Climatological flash flood events were recorded in 1992, 1994, 2003 and 20062010 and 2011 in southern and northern Sindh, but events with high intensity were more frequent in the coastal part of the southern Sindh.

\section{FLOOD IMPACT IN LOWER SINDH REGION}

Heavy rainfalls caused disasters in the lower region of Sindh and huge amounts of rainwater were accumulated in the land, villages and towns situated in the southern part of Sindh. The local people made relief cuts in irrigation channels for saving mature crops and households on a temporary and short strategy basis. Several breaches occurred in the banks of main and branch canals. Major breaches occurred in Fuleli canal, Akram wah and Nara canal system and also several breaches 
occurred in the main and branch drains of the LBOD system. Almost all the drainage system was damaged and overtopped due to overwhelming rainfall intensity. The designed capacity of the Spinal drainage was 4600 cusecs while the cumulative discharge was about 14,000 cusecs. The official land utilization statistics of Sindh show that all cotton area, $50 \%$ of the rice and fodder crops, and a smaller percentage of sugarcane area were damaged. The statistics were worked out through the use of satellite remote sensing technology. The affected cotton area is 45.9 thousand ha and the production loss was estimated at around 0.34 million bales. The rice area damaged is estimated at 32.4 thousand ha and the rice production loss was estimated at 99.9 thousand tons. Sugarcane crop was generally affected in a minor degree. The damages were estimated by SUPARCO through satellite remote sensing. The cultivated area in Sindh is 4.89 million ha. The net sown area over a year is 2.81 million ha and the fallow area over a year is 2.08 million ha. This is almost a ratio of $60 \%$ cropped area and $40 \%$ fallow area. However, in view of our assessments it is assumed that cropped area is $70 \%$ and fallow area is $30 \%$ [22].

\section{CONCLUSIONS}

Monsoon rains of 2011 were the most intense event in the history of Pakistan. The heavy rainfall flash flooded the whole area of lower Sindh. Relief cuts were made in the irrigation and drainage network for saving crops and households but this worsened the situation, this water entered the spinal system, which was forced to deal with about 14000 cusecs discharge against the designed 4600 cusecs. This resulted to overtopping of the Mirpurkhas Main Drain, Spinal and Doro Puran Outfall Drain at various places, particularly at where the constructed drains intersect the Dhoro Puran natural water way. The major reason of this disaster was the small carrying capacity of the LBOD system, but also we have to point out that the drainage system was chocked, the natural waterways were blocked by altered agriculture lands, construction of roads, having inadequate size and number of culverts and aqueducts over drains, consequently overtopping the drainage and irrigation networks. Sindh Irrigation and Drainage Authority (SIDA) and Area Water Boards (AWBs) have as goals to introduce reforms in the water sector and to restore equitable and reliable water delivery of the irrigation system. Their functions are operation, maintenance and rehabilitation of canals, distributaries and minor networks, maintenance, rehabilitation and monitoring of the main drainage system, construction, operation and maintenance of the outfall drains, receiving effluent drainage water from AWBs and convey it to the sea, maintain the flood protection infrastructure along river Indus, and overall to act as the prime agent of change, advising AWBs and farmer organizations (FOs).

It is concluded that to enhance the capacity of LBOD and Kotri surface drainage system for safe disposal of extraordinary rainfall from its watershed area, the best should be made from the use of the existing facilities and natural waterways based upon realistic hydro-meteorological analyses for draining out rainwater. Facilities, monitoring tools, weather radars, and digital rain gauge stations must be provided in order to forecast more reliably heavy disasters, in order to perform more succesfully risk management and preparedness plans in southern Sindh.

\section{ACKNOWLEDGMENTS}

Authors are thankful to the Sindh Irrigation and Drainage Authority and the Left Canals Area Water Board for providing the data and facilities for this research.

\section{REFERENCES}

[1] M. A. Melieres, C. Marechal, Climate Change: Past, Present, and Future, John Wiley \& Sons, 2015

[2] A. A. Mahessar, A. L. Qureshi, G. H. Dars, M. A. Solangi, "Climate change impacts on vulnerable Guddu and Sukkur barrages in Indus river, Sindh", Sindh University Research Journal (Science Series), Vol. 49, No. 1, pp. 137-142, 2017

[3] Q. U. Z. Chaudhry, Climate Change Profile of Pakistan, Asian Development Bank, 2017

[4] Oxfam, Climate Change in Pakistan: Stakeholder Mapping and Power Analysis, Oxfam, 2009

[5] J. J. McCarthy, O. F. Canziani, N. A. Leary, D. J. Dokken, K. S. White, Climate Change 2001: Impacts, Adaptation and Vulnerability, Cambridge University Press, 2001

[6] M. V. Aalst, Managing Climate Risk: Integrating Adaptation into World Bank Group Operations, World Bank Group: Global Environment Facility Program, 2006

[7] Y. Xu, X. Huang, Y. Zhang, W. Lin, E. Lin, "Statistical analyses of climate change scenarios over China in the 21 st century", Advances in Climate Change Research, Vol. 2, No. 1, pp. 50-53, 2006

[8] J. S. Dukes, J. Pontius, D. Orwig, J. R. Garnas, V. L. Rodgers, N. Brazee, B. Cooke, K. A. Theoharides, E. E. Stange, R. Harrington, J. Ehrenfeld, J. Gurevitch, M. Lerdau, K. Stinson, R. Wick, M. Ayres, "Responses of insect pests, pathogens, and invasive plant species to climate change in the forests of northeastern North America: What can we predict?", Canadian Journal of Forest Research, Vol. 39, No. 2, pp. 231-248, 2009

[9] T. Mitchell, T. Tanner, Adapting to Climate Change: Challenges and Opportunities for the Development Community, Institute of Development Studies, 2006

[10] A. Dinar, R. Hassan, R. Mendelsohn, J. K. A. Benhin, Climate Change and Agriculture in Africa: Impact Assessment and Adaptation Strategies, Routledge, 2012

[11] J. A. Dixon, D. P. Gibbon, A. Gulliver, Farming Systems and Poverty: Improving Farmers' Livelihoods in a Changing World, Food \& Agriculture Organization of the United Nations, 2001

[12] J. Briscoe, U. Qamar, Pakistan's Water Economy: Running Dry, Oxford University Press, 2006

[13] R. Agnihotri, K. Dutta, W. Soon, “Temporal derivative of total solar irradiance and anomalous indian summer monsoon: An empirical evidence for a sun-climate connection", Journal of Atmospheric and Solar-Terrestrial Physics, Vol. 73, No. 13, pp. 1980-1987, 2011

[14] Y. Y. Loo, L. Billa, A. Singh, "Effect of climate change on seasonal monsoon in Asia and its impact on the variability of monsoon rainfall in Southeast Asia”, Geoscience Frontiers, Vol. 6, No. 6, pp. 817-823, 2015

[15] A. A. Mahessar, A. L. Qureshi, A. Baloch, "Flood forecasting for the super flood 2010 in sukkur-kotri reach of indus river", International Water Technology Journal, Vol. 3, No. 4, pp. 255-262,2015

[16] S. Das, S. V. Singh, E. N. Rajagopal, R. Gall, "Mesoscale modeling for mountain weather forecasting over the Himalayas", Bulletin of the American Meteorological Society, Vol. 84, No. 9, pp. 1237-1244, 2003

[17] G. Rasul, Q. U. Z. Sixiong, Z. Sixiong, Z. Qingcun, “A diagnostic study of record heavy rain in twin cities Islamabad-Rawalpindi", Advances in Atmospheric Sciences, Vol. 21, No. 6, pp. 976-988, 2004

[18] M. Murshed, "Does improvement in trade openness facilitate renewable energy transition? evidence from selected South Asian economies", South Asia Economic Journal, Vol. 19, No. 2, pp. 151-170, 2018 
[19] A. A. Mahessar, K. C. Mukwana, A. Qureshi, M. Ehsan, H. Leghari, A. L. Manganhar, "Assessment of water quality of LBOD system and environmental concerns", Quaid-E-Awam University Research Journal of Enginnering, Science \& Technology, Vol. 15, No. 1, pp. 32-39, 2016

[20] A. A. Mahessar, A. L. Qureshi, A. N. Laghari, S. Qureshi, S. F. Shah, F. A. Shaikh, "Impact of Hairdin, Miro Khan and Shahdad Kot drainage on Hamal Dhand, Sindh", Engineering, Technology \& Applied Science Research, Vol. 8, No. 6, pp. 3652-3656, 2018

[21] C. A. Gandarillas, M. Saleh Soomro, A. Nazir, A. A. Dasti Baloch, A. Turangzai, A. Javed, B. A. Shahid, D. Veselinovic, F. Samo, G. R. Keerio, J. E. Priest, K. Ansari, K. H. Soofi, M. Silver, M. S. Samo, N. Ibrahim, R. Tabassum, R. Renfro, R. Wilkins, S. U. Zafar, S. Ali Soomro, S. M. Akhtar, S. A. H. Jagirdar, T. K. Baloch, U. G. Dar, Z. Saeed, Z. Habib, Z. Mangrio, Regional Master Plan for the Left Bank of Indus, Delta and Coastal, Sindh Irrigation and Drainage Authority, 2013

[22] Suparco, Pakisttan Rain/Flood 2011: Report on Flash Floods, Bbreaches in Canals and Damage to Infrastructure \& Agriculture Sectors in Sind Province, Suparco, 2011 